\title{
Early Holocene fauna from a new subfossil site: A first assessment from Christmas River, south cen- tral Madagascar
}

Kathleen M. Muldoon ',"I, Brooke E. Crowley"', Laurie R. Godfrey ${ }^{\mathrm{IV}}$, Armand Rasoamiaramananav, Adam Aronson ${ }^{\mathrm{VI}}$, Jukka Jernvall ${ }^{\mathrm{VII}}$, Patricia C. Wright ${ }^{\mathrm{VI}}$ and Elwyn L. Simons ${ }^{\text {VIII }}$

\begin{abstract}
We report on faunal remains recovered during recent explorations at 'Christmas River', the only subfossil locality known from Madagascar's south central plateau. Recovered remains of several extinct taxa date to approximately $10,000{ }^{14} \mathrm{C}$ years before present (BP), including crocodiles, tortoises, the elephant bird Aepyornis, the carnivoran Cryptoprocta spelea, the lemurs Archaeolemur majori, Pachylemur insignis, and Megaladapis edwardsi, and abundant remains of the dwarf hippopotamus, Hippopotamus lemerlei. The presence of southern-limited, forest-dependent species at Christmas River supports the hypothesis that forest once extended, perhaps discontinuously, across the central highlands towards the west. One theory is that sites in the north central highlands, which are higher in elevation, maintained more mesic conditions during Plio-Quaternary climate shifts than those of the lower elevation sites of the south central highlands. Thus, elevation above sea level may have acted as a filter that limited species dispersal across the island in the past. Such a scenario would explain the distinction between more humid, higher elevation, northern highland subfossil communities versus more arid, lower elevation, southern subfossil communities. Continued exploration at Christmas River thus provides a remarkable opportunity for deciphering ecological changes that have taken place in south central Madagascar during the Holocene.
\end{abstract}

\section{RÉSUMÉ}

Madagascar est reconnue comme I'une des régions les plus sensibles du monde en ce qui concerne les menaces pesant sur sa biodiversité, et cela à cause de niveaux d'endémisme inégalés, d'une diversité variée et d'un impact humain important sur l'environnement. Suite à la colonisation par l'Homme il y a plus de 2000 ans, des extinctions de masse de la faune et un important recul forestier ont eu lieu en laissant des marques sur

\section{Correspondence:}

\section{Kathleen M. Muldoon}

Department of Anatomy, The Geisel School of Medicine at Dartmouth, HB 7100, Hanover, New Hampshire 03755 U.S.A.

E-mail: kathleen.muldoon@dartmouth.edu

les écosystèmes modernes qui sont dans un état de bouleversement écologique. Certaines plantes endémiques, par exemple, ont perdu d'importantes espèces mutualistes, des animaux ont été obligés d'exploiter d'autres ressources ou habiter des endroits auxquels ils sont mal adaptés. La diversité des plantes et des animaux a diminué, est menacée ou a même complètement disparue de certaines routes de dissémination. Bien que I'Homme soit largement incriminé dans son rôle de déclencheur de ces extinctions massives, les transformations anthropiques qui ont contribué au changement du climat sont controversées. Les hautes-terres de Madagascar sont actuellement dominées par des zones herbeuses étendues qui agissent comme des barrières empêchant les mouvements de la faune de part et d'autre de l'île. Nous suggérons qu'une forêt humide plus ou moins continue devait s'étendre sur les hautes-terres. Des informations paléoécologiques des hautes-terres du Centre sud sont nécessaires pour évaluer cette hypothèse afin de démêler la contribution relative des facteurs climatiques et anthropiques dans les changements paléoécologiques de la région. Cependant, les stations de subfossiles étaient jusqu'alors inconnues dans cette région.

Nous présentons ici les résultats de recherches réalisées sur les restes fauniques découverts au cours de fouilles récentes à Christmas River, la seule station de subfossiles connue des hautes-terres du Centre sud de Madagascar. Des restes de plusieurs espèces datant approximativement de $10,000{ }^{14} \mathrm{C}$ B.P. ont été identifiés dont des restes appartenant à des espèces de crocodile, de tortue, de I'Aepyornis, du carnivore Cryptoprocta spelea, des lémuriens Archaeolemur majori, Pachylemur insignis et Megaladapis edwardsi ainsi que de nombreux restes de I'hippopotame nain Hippopotamus lemerlei. La présence à Christmas River d'espèces sylvicoles endémiques du Sud appuie I'hypothèse de l'existence d'une forêt, certainement discontinue, mais qui s'étendait sur les hautes-terres centrales en se

Department of Anatomy, The Geisel School of Medicine at Dartmouth, HB 7100, Hanover, New Hampshire 03755 U.S.A.

Department of Anthropology, Dartmouth College, HB 7100, Hanover, New Hampshire 03755 U.S.A.

Departments of Geology and Anthropology, University of Cincinnati, Cincinnati OH 45221 U.S.A.

Department of Anthropology, University of Massachusetts, Amherst, Amherst MA 01003 U.S.A.

Département de Paléontologie et Anthropologie Biologique, Université d'Antananarivo, Antananarivo, Madagascar.

Institute for the Conservation of Tropical Environments, Stony Brook University, Stony Brook NY, U.S.A.

Developmental Biology Program, Institute of Biotechnology, and Department of Ecology and Systematics, University of Helsinki, 00014 Helsinki, Finland.

Division of Fossil Primates, Duke University Lemur Center, Duke University, Durham, North Carolina 27705 U.S.A. 
poursuivant vers I'ouest. Une théorie a proposé que les sites septentrionaux des hautes-terres centrales, à des altitudes plus élevées, maintenaient des conditions plus humides au cours des changements du Plio-quaternaire que les sites méridionaux de ces hautes-terres centrales. Ainsi, dans le passé, I'altitude a du agir comme un filtre qui empêchait la dispersion des espèces d'un endroit à l'autre de l'île. Un tel scénario expliquerait la distinction entre les communautés subfossiles du nord des hautes-terres qui étaient plus humides à haute altitude et les communautés subfossiles du sud aride à basse altitude. La poursuite de l'exploration à Christmas River constitue une occasion unique pour décoder les changements écologiques qui sont intervenus dans le sud de cette région centrale de Madagascar au cours de I'Holocène.

\section{INTRODUCTION}

Madagascar is considered a hotspot for endangered biodiversity, based on unequaled levels of endemism, species diversity, and human impact on the environment (Goodman and Benstead 2005). Following human colonization more than 2,000 years ago, Madagascar experienced well-documented megafaunal extinctions and widespread deforestation (Burney et al. 2004, Crowley 2010), leaving many elements of modern ecosystems in a state of ecological disruption. For example, endemic plants have lost important mutualists (Godfrey et al. 2008), animals have been forced to exploit resources or live in habitats to which they are poorly adapted (Cuozzo and Sauther 2006, Crowley et al. 2012, Godfrey et al. 2012), and both plants and animals have reduced, threatened, or entirely eliminated dispersal routes (Godfrey et al. 1999, Goodman et al. 2006, 2007, Muldoon et al. 2009, Muldoon 2010). Although humans are widely considered to be the primary trigger of megafaunal extinctions (Burney 1999, Burney et al. 2003, 2004, Godfrey and Irwin 2007, Crowley 2010), the relative contributions of climate change and human activities to this ecological transformation are contested (e.g., Virah-Sawmy et al. 2009a,b, 2010).

Isolated patches of modern forest that is markedly more humid than surrounding areas in the southwest at Analave-

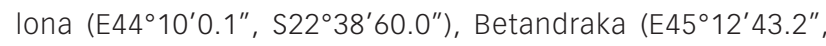

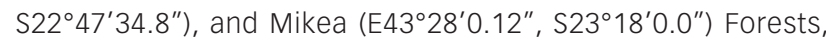
Zombitse-Vohibasia $\left(E 48^{\circ} 49^{\prime} 0.1^{\prime \prime}, \mathrm{S} 22^{\circ} 37^{\prime} 0.12^{\prime \prime}\right)$, and Isalo (E45 $19^{\prime} 55.2^{\prime \prime}, \mathrm{S} 22^{\circ} 30^{\prime} 3.6^{\prime \prime}$ ) National Parks, and in the southeast at Grand Lavasoa (E46 $\left.43^{\prime} 60.0^{\prime \prime}, \mathrm{S} 25^{\circ} 4^{\prime} 59.9^{\prime \prime}\right)$ and Ambatorongorongo (E46 $\left.43^{\prime} 60.0^{\prime \prime}, \mathrm{S} 25^{\circ} 4^{\prime} 59.9^{\prime \prime}\right)$ may be relicts of a prior humid forest corridor across southern Madagascar (Ramanamanjato et al. 2002, Goodman and Ramanamanjato 2007, Moat and Smith 2007) (Figure 1). Today, the central highlands are dominated by grasslands that act as a significant barrier to faunal exchange across the island (Muldoon and Goodman 2010). However, the subfossil record of southern Madagascar reveals that numerous extant species once occurred in regions where they do not live today (Goodman and Rakotondravony 1996, Goodman and Rakotozafy 1997, Godfrey et al. 1999, Goodman et al. 2006, 2007, Muldoon et al. 2009). To account for these distributional records, some authors have suggested that humid forest once extended, perhaps discontinuously, across the central highlands. One hypothesis is that a forested corridor extended westward across the southern portion of the central highlands from the region of Andringitra Massif (approximately south of $20^{\circ}$ latitude), allowing the westward dispersal of animals adapted to moist environ- ments (Goodman and Rakotondravony 1996, Goodman and Rakotozafy 1997, Goodman and Ramanamanjato 2007). Presumably, this corridor has been fragmented by climate change (Virah-Sawmy et al. 2009a,b) or human-initiated deforestation (Ganzhorn et al. 2001, Burney et al. 2004, Consiglio et al. 2006). Building a paleoecological record of the south central highlands is essential to disentangling the relative contributions of climatic and human factors to paleoenvironmental change in this region, but subfossil sites were unknown from this area until recently. We report preliminary findings from the newly discovered paleontological site that we name 'Christmas River', located in the region of the hypothesized southern faunal corridor.

\section{MATERIALS AND METHODS}

STUDY SITE. In 2008, paleontological reconnaissance in the south central highlands of Madagascar resulted in the discovery of a significant new paleontological site. This site, called 'Christmas River', is located along the Ihazofotsy River on the east side of the southernmost region of the Isalo Massif (E4536'21.6", S22³0'3.6", 793 m above sea level; Figure 1). Christmas River is the only subfossil locality known from this region. All fauna recovered from this locality are therefore first known regional occurrences. Christmas River was discovered following on an observation by a sapphire miner, who located a bone bed 10-15 m deep in 2006. Sapphire miners focused on the collection of large macrofossils, and the younger layers of the pit have not yet been fully explored. A sample of sediment collected from the surface and subsurface at Christmas River indicates the presence of small vertebrate and botanical remains.

Approximately 600 vertebrate specimens, representing mammals, birds, and herpetofauna, have been collected from Christmas River to date. Skeletal remains in the mammalian assemblage demonstrate a high quality of preservation and include largely complete crania, jaws, isolated teeth, and postcranial elements. All skeletal material recovered from Christmas

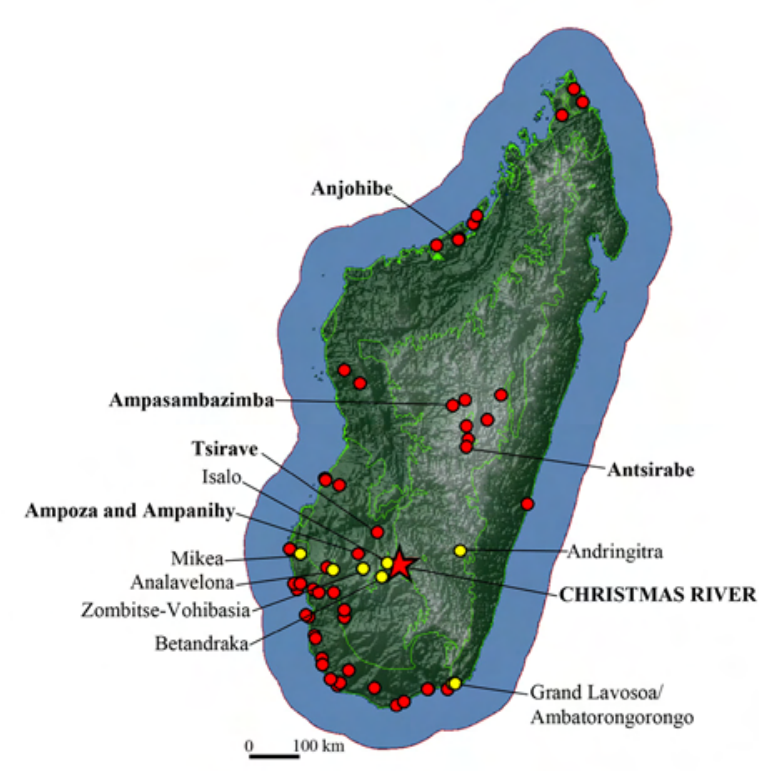

FIGURE 1. Map showing the position of Christmas River (red star), relative to modern forest sites (regular font, yellow dots) and other subfossil localities (bold font, red dots). Dashed green lines indicate the boundaries between ecoregions, following Burgess et al. (2004). Notice the unique position of Christmas River in the south central highlands, within the region of the hypothesized southern dispersal corridor. 
River has been collected and studied as part of collaborative efforts between the Duke University Lemur Center, Division of Fossil Primates (Durham, North Carolina, U.S.A.), and Dartmouth College (Hanover, New Hampshire, U.S.A.), with the Département de Paléontologie et Anthropologie Biologique, Université d'Antananarivo (Antananarivo, Madagascar), respectively.

Morphological analysis of the Christmas River mammals was completed in comparison with reference material housed at the Département de Paléontologie et Anthropologie Biologique, Université d'Antananarivo (Antananarivo, Madagascar), the Natural History Museum (London, England), the Muséum national d'Histoire naturelle (Paris, France), the Naturhistorisches Museum (Vienna, Austria), the American Museum of Natural History (New York, New York, U.S.A.), The Field Museum of Natural History (Chicago, Illinois, U.S.A.), the University of Massachusetts, Amherst (Amherst, Massachusetts, U.S.A.), as well as published descriptions. Qualitative comparisons and quantitative skeletal variables were recorded for each specimen examined following anatomical landmarks defined and illustrated in Steunes (1989) and Weston and Lister (2009) for Hippopotamus; Jouffroy (1963) for Archaeolemur and Pachylemur; Lamberton (1934) for Megaladapis; Goodman et al. (2004) for cryptoprocta.

We selected several bones for radiocarbon dating. These bones were decalcified and gelatinized using EDTA and weak $\mathrm{HCl}$, respectively (Crowley 2012). We confirmed collagen preservation using collagen yield and atomic $\mathrm{C}$ : $\mathrm{N}$ ratios (values falling between 2.9 and 3.6 were considered well preserved). Samples were radiocarbon dated at the University of Helsinki and the Center for Accelerator Mass Spectrometry at Lawrence Livermore National Laboratory.

\section{RESULTS}

Christmas River differs from most open-air deposits in Madagascar in that it has the potential to yield a stratigraphic profile in the sense of vertical, chronological relations of sedimentary units. The deepest and most prolific layer reached so far at Christmas River is a grey-green clay containing the bones of several extinct taxa including crocodiles, tortoises, the elephant bird Aepyornis, and abundant remains of the dwarf hippopotamus, Hippopotamus lemerlei. Bones from this layer yielded AMS ${ }^{14} \mathrm{C}$ dates of approximately 10,000 uncalibrated ${ }^{14} \mathrm{C}$ years BP (Table 1). The Hippopotamus specimens from Christmas River therefore represent the oldest data for this genus in Madagascar.

The Hippopotamus specimens from Christmas River can be attributed to $\mathrm{H}$. lemerlei on the basis of the following qualitative characters: a thick supraorbital margin that results from a large frontal sinus that extends laterally, an orbit that is taller than it is wide, the anterior margin of the orbit is situated above the third upper molar (M3), a long and flat mandibular symphysis (Figure 2a-c). The Christmas River specimens are intermediate in size between H. lemerlei and H. madagascariensis (Figure 3).

The extinct lemur Megaladapis edwardsi was recovered from lower levels, but did not have enough collagen to produce an accurate radiocarbon date (Figure 2g). Megaladapis edwardsi differs from both $M$. madagascariensis and $M$. grandidieri in having significantly larger molars (especially the third molars, which are the longest and widest). Neither of the two partial mandible specimens recovered had intact molar rows. However,
TABLE 1. Radiocarbon ages for vertebrate bones collected from Christmas River. Calibrated ages were calculated using Calib 6.0, the Southern Hemisphere Calibration Curve (ShCal04) and a 20-year moving average (Stuiver and Reimer 1993, McCormac et al. 2004). Calibrated ages are rounded to the nearest 5 years ${ }^{14} \mathrm{C}$ Laboratory Codes: $\mathrm{CAMS}=$ The Center for Accelerator Mass Spectrometry, Lawrence Livermore Nationa Laboratory; Hela = University of Helsinki.

\begin{tabular}{|l|l|c|c|l|}
\hline $\begin{array}{l}\text { Genus and } \\
\text { Species }\end{array}$ & Specimen \# & $\begin{array}{c}14 \text { C yr BP } \\
\pm 1 \mathrm{~S}\end{array}$ & $\begin{array}{c}\text { Cal yr BP } \\
\pm 1 \mathrm{~S}\end{array}$ & Lab \# \\
\hline $\begin{array}{l}\text { Archaeolemur sp. } \\
\text { cf. A. majori }\end{array}$ & DPC 24153a & $\begin{array}{c}9265 \\
\pm 30\end{array}$ & $\begin{array}{c}10345 \\
\pm 95\end{array}$ & CAMS 147334 \\
\hline $\begin{array}{l}\text { Pachylemur } \\
\text { insignis }\end{array}$ & DPC 24156 & $\begin{array}{c}9450 \\
\pm 30\end{array}$ & $\begin{array}{c}10615 \\
\pm 95\end{array}$ & CAMS 147038 \\
\hline Hippopotamus & & 9655 & 10955 & Hela-1828 \\
lemerlei & & \pm 60 & \pm 215 & \\
\hline Aepyornis sp. & & 9610 & 10920 & Hela 1829 \\
\hline Aepyornis sp. & & 9535 & 10825 & Hela 1774 \\
\hline
\end{tabular}

one specimen preserves $\mathrm{m} 2$ and a partial $\mathrm{m} 3$, and the approximate mesiodistal lengths of all three molars were estimated from the sizes of the alveoli for the two missing teeth ( $m 1=18.0$ $\mathrm{mm}, \mathrm{m} 2=24.0 \mathrm{~mm}, \mathrm{~m} 3=35.0 \mathrm{~mm}$ ). Based on these estimated size dimensions, both mandibles can be assigned to the larger species, $M$. edwardsi ( $\mathrm{m} 1=17.2 \pm 0.6 \mathrm{~mm}[\mathrm{n}=43], \mathrm{m} 2=22.9$ $\pm 0.9 \mathrm{~mm}[\mathrm{n}=63], \mathrm{m} 3=34.8 \pm 1.5 \mathrm{~mm}[\mathrm{n}=70])$.

Isolated remains found above the grey-green clay layer include the distal left humerus of Archaeolemur sp. cf. majori that is broken just below the deltoid crest, but with a largely intact distal epiphysis and olecranon fossa (DPC 24153a; Figure 2e). This specimen dates to $9,265 \pm 30{ }^{14} \mathrm{C}$ yr BP (Table 1). Additionally, Pachylemur insignis is represented by the distal two-thirds of a left femur that is broken at the level of the third trochanter (DPC 24156; Figure 2f), which yielded a date of 9,450 $\pm 30{ }^{14} \mathrm{C}$ yr BP (Table 1). These specimens exhibit diagnostic features for each genus: for example, for Archaeolemur, a posteromedially deflected entepicondyle; and for Pachylemur, a relatively deep patellar groove with a raised lateral lip and anteroposteriorly compressed femoral shaft. Both of these specimens fall within the range of size variation of the southwestern species of their respective genus (e.g., A. majori and $P$. insignis), although the Archaeolemur humerus lies at the high end of its range (Table 2), while the Pachylemur femur falls at the low end of its range (Table 3). We note, however, that there is a distinct latitudinal body size gradient in Archaeolemur, such that body size tends to be smallest in the extreme south, and larger in the center and north of the island of Madagascar (Albrecht et al. 1990, Godfrey et al. 1990). The specimen from Christmas River is larger than most specimens at sites to the south and west, but similar in size to A. majori humeri from Tsirave (E45⒎ $1^{\prime}, \mathrm{S} 21^{\circ} 49.6^{\prime}, 745$ $m$ a.s.I.), a subfossil site just north of the Isalo Massif.

A distal humerus (DPC 24153b; Figure 2d) attributable to the extinct carnivoran cryptoprocta spelea on the basis of its large size was also recovered. The width of the distal humerus of DPC 24153b is $36.4 \mathrm{~mm}$, which is larger than the same measurement in modern $(27.9 \pm 1.4 \mathrm{~mm}, \mathrm{n}=12)$, or subfossil $(32.1 \pm 2.6$ $\mathrm{mm}, \mathrm{n}=27$ ) Cryptoprocta ferox, but similar in size to the largerbodied extinct $C$. spelea (33.7 \pm 1.7 mm; Goodman et al. 2004). Similar to the specimens of Megaladapis, collagen preservation for this specimen was too poor to produce a radiocarbon date (low yield, high atomic C:N). 


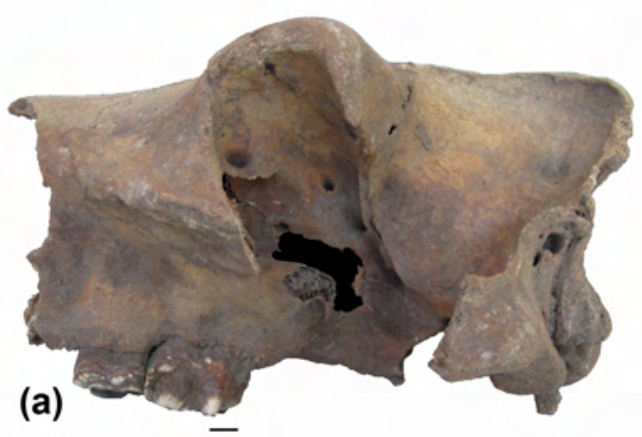

(d)

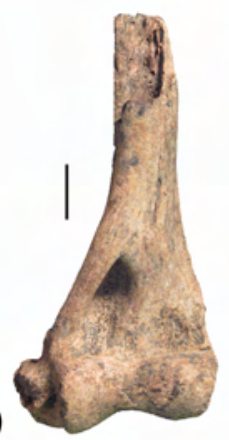

(e)

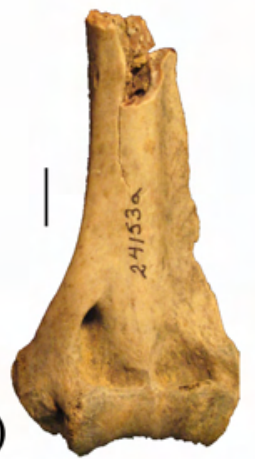

(f)

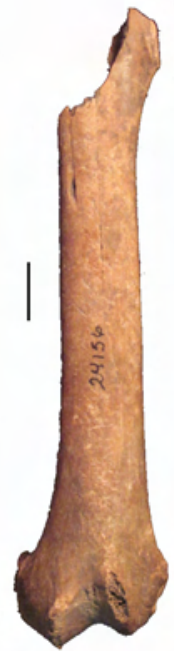

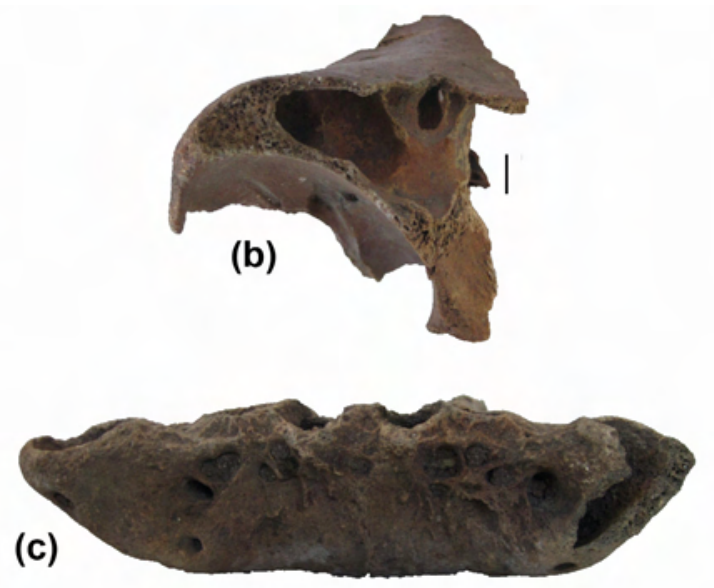

(c)
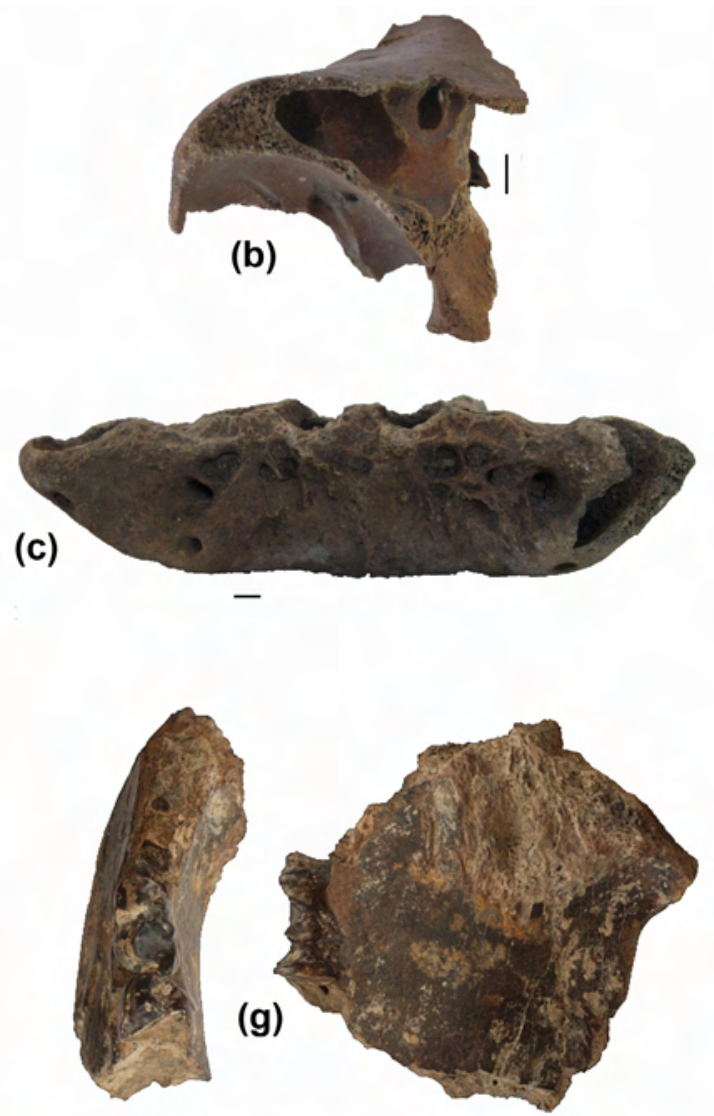

$\overline{1 \mathrm{~cm}}$

FIGURE 2. Representative mammal fauna from Christmas River. Hippopotamus lemerlei (a) skull (08-CR-001a) in lateral view; (b) partial skull (08-CR-002n) in posterior view; (c) mandible (08-CR-006) in anterior view; (d). Cryptoprocta spelea left distal humerus (DPC 24153b) in anterior view; (e) Archaeolemur sp. cf. A. majori left distal humerus (DPC 24153a) in anterior view; (f) Pachylemur insignis partial left femur (DPC 24156) in anterior view; (g) Megaladapis edwardsi (unnumbered) in occlusal and lateral views. Scale bars equal $1 \mathrm{~cm}$.

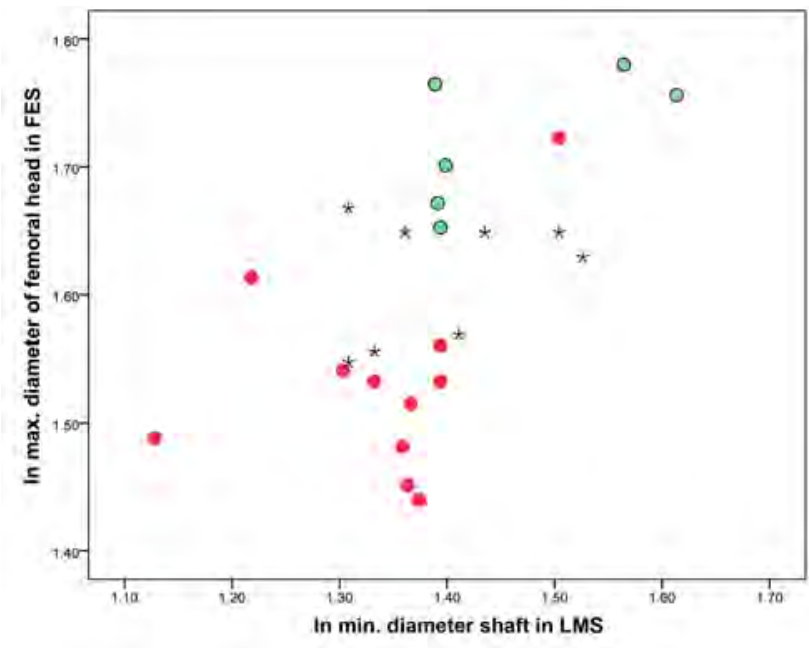

FIGURE 3. Scatterplot showing separation of Hippopotamus lemerlei (red dots) and $H$. madagascariensis (green dots) based on femoral measurements. The Christmas River specimens (black stars) are significantly larger than $H$. lemerlei $(t=-3.067$, d.f. $=20, P<0.05)$, and significantly smaller than $H$. madagascariensis $(t=4.165$, d.f. $=10, P<0.05)$ in femoral head diameter, but cannot be distinguished from either species based on femoral shaft width (for comparisons with $H$. lemerlei, $t=-1.974$, d.f. $=27, P=0.59$; for comparisons with $H$. madagascariensis, $t=-0.270$, d.f. $=14, P=0.791$ ). $\mathrm{FES}=$ flexor-extensor section; $\mathrm{LMS}=$ lateral-medial section (following Weston and Lister 2009).
TABLE 2. Descriptive measurements for south and southwest variants of Archaeolemur majori, compared with specimens from Tsirave and Christmas River. Measurements (in $\mathrm{mm}$ ) are presented as mean \pm standard deviation.

\begin{tabular}{|c|c|c|c|}
\hline & $\begin{array}{l}\text { South and } \\
\text { Southwest }\end{array}$ & Tsirave & $\begin{array}{l}\text { Christmas } \\
\text { River }\end{array}$ \\
\hline \multirow{2}{*}{ Biepicondylar breadth } & $33.6 \pm 1.5$ & $35.7 \pm 2.7$ & \multirow{2}{*}{38} \\
\hline & $n=6$ & $n=6$ & \\
\hline \multirow{2}{*}{ Trochlea to medial epicondyle } & $27.8 \pm 1.4$ & $29.3 \pm 2.0$ & \multirow{2}{*}{29.2} \\
\hline & $\mathrm{n}=35$ & $n=6$ & \\
\hline \multirow{2}{*}{ Trochlea + capitulum width } & $25.0 \pm 1.4$ & $26.0 \pm 1.6$ & \multirow{2}{*}{27.4} \\
\hline & $n=33$ & $n=6$ & \\
\hline \multirow{2}{*}{ Capitulum width } & $10.3 \pm 0.8$ & $10.9 \pm 0.5$ & \multirow{2}{*}{12} \\
\hline & $n=34$ & $n=6$ & \\
\hline \multirow{2}{*}{ Trochlear depth } & $11.9 \pm 1.0$ & $12.4 \pm 1.6$ & \multirow{2}{*}{12.4} \\
\hline & $n=34$ & $n=6$ & \\
\hline \multirow{2}{*}{ Olecranon fossa width } & $16.9 \pm 1.2$ & $17.5 \pm 1.0$ & \multirow{2}{*}{19.5} \\
\hline & $n=37$ & $n=6$ & \\
\hline \multirow{2}{*}{ Olecranon fossa height } & $9.2 \pm 1.2$ & $10.4 \pm 0.8$ & \multirow{2}{*}{11.4} \\
\hline & $\mathrm{n}=37$ & $n=6$ & \\
\hline
\end{tabular}


TABLE 3. Descriptive measurements for Pachylemur insignis and P. jullyi, compared with specimens from Christmas River. Measurements (in $\mathrm{mm}$ ) are presented as mean \pm standard deviation. $\mathrm{AP}=$ anterior-posterior dimension.

\begin{tabular}{|c|c|c|c|}
\hline & P. insignis & P. jullyi & $\begin{array}{l}\text { Christmas } \\
\text { River }\end{array}$ \\
\hline \multirow{2}{*}{ midshaft AP diameter } & $11.8 \pm 0.8$ & $12.5 \pm 0.7$ & \multirow{2}{*}{10.4} \\
\hline & $n=14$ & $n=6$ & \\
\hline \multirow{2}{*}{ midshaft transverse diameter } & $13.0 \pm 0.8$ & $14.3 \pm 1.8$ & \multirow{2}{*}{14.6} \\
\hline & $n=14$ & $n=2$ & \\
\hline \multirow{2}{*}{ biepicondylar diameter } & $27.5 \pm 1.4$ & 29 & \multirow{2}{*}{28.4} \\
\hline & $n=14$ & $n=2$ & \\
\hline \multirow{2}{*}{ bicondylar diameter } & $26.4 \pm 1.2$ & 28 & \multirow{2}{*}{27.8} \\
\hline & $n=14$ & $n=2$ & \\
\hline \multirow{2}{*}{ intercondylar diameter } & $8.7 \pm 0.8$ & 9.5 & \multirow{2}{*}{8} \\
\hline & $n=14$ & $n=2$ & \\
\hline \multirow{2}{*}{ patellar breadth } & $12.8 \pm 0.9$ & 11.5 & \multirow{2}{*}{12.9} \\
\hline & $n=14$ & $n=2$ & \\
\hline \multirow{2}{*}{ medial condyle AP depth } & $23.3 \pm 1.0$ & 24.8 & \multirow{2}{*}{23.9} \\
\hline & $n=14$ & $n=2$ & \\
\hline \multirow{2}{*}{ lateral condyle AP depth } & $24.1 \pm 1.1$ & 25 & \multirow{2}{*}{24} \\
\hline & $n=14$ & $n=2$ & \\
\hline
\end{tabular}

\section{DISCUSSION}

The importance of Christmas River for understanding the paleoecological history of the south central highlands of Madagascar is demonstrated by its unique fauna. The mammalian subfossil assemblage is dominated by Hippopotamus lemerlei, an extinct species previously recovered almost exclusively from coastal areas in the southern region of the island (Steunes 1989, Jernvall et al. 2003). The distinguishing morphological characteristics of $\mathrm{H}$. lemerlei, which include an orbit that is taller than it is wide, suggest an amphibious lifestyle similar to $H$. amphibius of modern Africa. This is in contrast to the terrestrial habits interpreted for $\mathrm{H}$. madagascariensis, which has been recovered from Ampasambazimba and Antsirabe, subfossil localities that occur well to the north of Christmas River in the mid-central highlands (Figure 1, Steunes 1989). We note here that attributions of the Anjohibe hippopotamus material to $\mathrm{H}$. lemerlei (Burney et al. 1997, Samonds et al. 2010) should be corrected to H. madagascariensis (Weston and Lister 2009), emphasizing the geographic and ecological separation of these species that was described by Steunes (1989). The nearest subfossil Iocalities to Christmas River are Ampoza (E44 $42.3^{\prime}, \mathrm{S}_{2}{ }^{\circ} 18.9^{\prime}$,

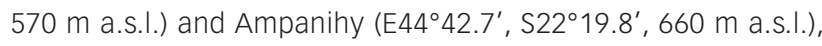
about $83 \mathrm{~km}$ further west (Mahé and Sourdat 1972, Jernvall et al. 2003). Although these localities yield much more recent dates (ca. $1,800{ }^{14} \mathrm{C}$ yr BP and $2,430{ }^{14} \mathrm{C}$ yr BP, respectively; Jernvall et al. 2003), the subfossil assemblages at these sites are also dominated by $\mathrm{H}$. lemerlei.

The extinct lemur taxa shared between Christmas River and Ampoza include inferred southern forest-dwelling animals such as Archaeolemur sp. cf. majori, Pachylemur insignis, and Megaladapis edwardsi (Jernvall et al. 2003). This lemur assemblage is fundamentally different from the species composition of a string of subfossil sites forming a corridor crossing the central highlands well to the north of Christmas River, through the Antananarivo ex Province (especially the Vakinankaratra and Itasy regions; e.g., Ampasambazimba, Figure 1). The only characteristically southern giant lemur that is unequivocally found within this mid-central highlands corridor is Hadropithecus stenognathus, which is rare. Other primate taxa from the midcentral highlands include the extinct lemurs Archaeolemur edwardsi, Megaladapis grandidieri, Archaeoindris fontoynontii, Mesopropithecus pithecoides, Pachylemur jullyi, and Palaeopropithecus maximus, as well as the extant lemurs Prolemur simus, Indri indri, Propithecus diadema, Eulemur fulvus, and Cheirogaleus major, among others. Sites in this more northern corridor, ranging from $914 \mathrm{~m}$ to over 1,645 m a.s.l., are higher in elevation than those in the south.

An east-west distance effect in extant mammal distributions has been interpreted as evidence that faunal exchange routes once crossed the southern portion of the central highlands (Godfrey et al. 1999, Muldoon and Goodman 2010). It has been hypothesized that this corridor was fragmented by shifts in vegetation associated with climate change, but given that much of the natural habitat across this zone no longer exists, it is difficult to reconstruct its former extent and type. Unfortunately, the Holocene fauna of the island's eastern rainforests is currently unknown. However, the subfossil record of southern Madagascar demonstrates that several extant species currently restricted to humid forests once had more widespread geographic distributions (Goodman and Rakotondravony 1996, Goodman and Rakotozafy 1997, Godfrey et al. 1999, Goodman et al. 2006, 2007, Muldoon et al. 2009, Muldoon 2010). Furthermore, the existence of relict patches of eastern rainforest flora and fauna in the west underscores recent habitat changes in southwestern Madagascar (Ramanamanjato et al. 2002, Goodman and Ramanamanjato 2007, Moat and Smith 2007). Elements of the extant fauna and flora of these areas have been used to suggest that these isolated humid and subhumid forests may serve as refugia for biota that had much more extensive distributions in southwestern Madagascar in the recentpast(Goodman and Rakotondravony 1996, Goodman and Rakotozafy 1997, Godfrey et al. 1999, Goodman et al. 2006, 2007, Muldoon et al. 2009, Muldoon 2010).

A preliminary paleoecological interpretation of the Christmas River site may offer an alternative explanation. One hypothesis is that the higher elevational distribution of sites in the north central versus south central highlands may have acted as a filter that limited species dispersal across the island in the past. Wilmé et al. (2006) proposed that watersheds with sources at high elevation maintained mesic conditions during Plio-Quaternary climate shifts due to orographic precipitation. For forest-dependent mammals, such mesic conditions may have allowed dispersal across the more northern-central passage, but limited dispersal of moisture-restricted animals in the south. For example, Megaladapis edwardsi is the dominant species at coastal southern sites, and may be restricted to spiny thicket habitat. Archaeolemur majori, and Pachylemur insignis are also largely restricted to the southern quadrant of Madagascar. Such a scenario would explain the distinction between more humid, higher elevation, northern highland subfossil communities versus more arid, lower elevation, southern subfossil communities. This hypothesis requires further exploration using explicit biogeographic tools.

\section{CONCLUSIONS}

The presence of forest-adapted, characteristically southern species at Christmas River provides support for two hypotheses: first, that a dispersal corridor likely once extended across the 
southern part of the central highlands. Preliminary evidence suggests that this corridor, perhaps discontinuously forested, could have been a northern extension of habitat typical of more southern regions, although a non-analog community of mixed eastern and southern plant communities cannot be excluded without paleoecological data. Second, it is clear that this corridor supported a primate assemblage that differed from primate communities further north. With further exploration, the faunal material from Christmas River will provide an unprecedented opportunity to decipher ecological changes that have taken place in south central Madagascar during the Holocene.

\section{ACKNOWLEDGEMENTS}

We appreciate the help of Désiré Randriarisata, Angelin Gilbert Razafitsihoarana, and local residents who participated in field work at Christmas River. Our work was carried out in collaboration with the Département de Paléontologie et Anthropologie Biologique, Universite d'Antananarivo and the Centre ValBio (Centre de Formation International pour la Valorisation de la Biodiversité). We especially thank Thérèse Périn-Deville for assistance with the French abstract. We would also like to acknowledge three anonymous reviewers. We are grateful to our funding sources: American Philosophical Society Franklin Research Grant, American Association of Physical Anthropologists Professional Development Award, The Claire Garber Goodman Fund to KMM, UCOP Lab Fees No. 115818 to BEC, University of Helsinki to JJ, National Science Foundation (SBR 96-30350), National Geographic Society (7692-04) to ELS. This is DLC publication number 1222.

\section{REFERENCES}

Albrecht, G. H., Jenkins, P. D. and Godfrey, L. R. 1990. Ecogeographic size variation among the living and subfossil prosimians of Madagascar. American Journal of Primatology 22, 1: 1-50. (doi:10.1002/ ajp.1350220102)

Burgess, N., Hales, J. D., Underwood, E., Dinerstein, E., Olson, D., Itoua, I., Schipper, J., Ricketts, T. and Newman, K. 2004. Terrestrial Ecoregions of Africa and Madagascar: A Conservation Assessment. Island Press, Washington, D.C.

Burney, D. A. 1999. Rates, patterns, and processes of landscape transformation and extinction in Madagascar. In: Extinctions in Near Time: Causes, Contexts, Consequences. R. D. E. MacPhee, (ed.), pp 145-164. Kluwer Academic/Plenum Publishers, New York.

Burney, D. A., James, H. F., Grady, F. V., Rafamantanantsoa, J.-G., Ramilisonina, Wright, H. T. and Cowart, J. B. 1997. Environmental change, extinction and human activity: Evidence from caves in NW Madagascar. Journal of Biogeography 24, 6: 755-767. (doi:10.1046/j.13652699.1997.00146.X)

Burney, D. A., Robinson, G. S. and Burney, L. P. 2003. Sporormiella and the late Holocene extinctions. Proceedings of the National Academy of Sciences U.S.A. 100, 19: 10800-10805. (doi:10.1073/pnas.1534700100)

Burney, D. A., Burney, L. P., Godfrey, L. R., Jungers, W. L., Goodman, S. M., Wright, H. T. and Jull, A. J. T. 2004. A chronology for late prehistoric Madagascar. Journal of Human Evolution 47, 1-2: 25-63. (doi:10.1016/j. jhevol.2004.05.005)

Consiglio, T., Schatz, G. E., McPherson, G., Lowry II, P. P., Rabenantoandro, J., Rogers, Z. S., Rabehovitra, R. and Rabehevitra, D. 2006 Deforestation and plant diversity of Madagascar's littoral forests. Conservation Biology 20, 6: 1799-1803. (doi:10.1111/j.15231739.2006.00562.x

Crowley, B. E. 2010. A refined chronology of prehistoric Madagascar and the demise of the megafauna. Quaternary Science Reviews 29, 19-20: 2592-2604. (doi:0.1016/j.quascirev.2010.06.030)
Crowley, B. E., Godfrey, L. R. and Irwin, M. T. 2011. A glance to the past: Subfossils, stable isotopes, seed dispersal, and lemur species loss in southern Madagascar. American Journal of Primatology 73, 1: 25-37. (doi:10.1002/ajp.20817)

Crowley, B. E. 2012. Stable isotope techniques and applications for primatologists. International Journal of Primatology 33, 3:673- 701. (doi:10.1007/s10764-012-9582-7)

Crowley, B. E., Godfrey, L. R., Guilderson, T. P., Zermeno, P., Koch, P. L. and Dominy, N. J. 2012. Extinction and ecological retreat in a community of primates. Proceedings of the Royal Society of London B. (doi:10.1098/ rspb.2012.0727)

Cuozzo, F. P. and Sauther, M. L. 2006. Severe wear and tooth loss in wild ring-tailed lemurs (Lemur catta): A function of feeding ecology, dental structure, and individual life history. Journal of Human Evolution 51, 5 : 490-505. (doi:10.1016/j.jhevol.2006.07.001)

Ganzhorn, J. U., Lowry II, P. P., Schatz, G. E. and Sommer, S. 2001. The biodiversity of Madagascar: One of the world's hottest hotspots on its way out. Oryx 35, 4: 346-348. (doi:10.1046/j.1365-3008.2001.00201.x)

Godfrey, L. R., Sutherland, M. R., Petto, A. J., and Boy, D. S. 1990. Size, space, and adaptation in some subfossil lemurs from Madagascar. American Journal of Physical Anthropology 81, 1: 45-66. (doi:10.1002/ ajpa.1330810107)

Godfrey, L. R. and Irwin, M. T. 2007. The evolution of extinction risk: Past and present anthropogenic impacts on the primate communities of Madagascar. Folia Primatologica 78: 405-419. (doi:10.1159/000105152)

Godfrey, L. R., Jungers, W. L., Simons, E. L., Chatrath, P. S. and Rakotosamimanana, B. 1999. Past and present distributions of lemurs in Madagascar. In: New Directions in Lemur Studies. B. Rakotosamimanana, H. Rasamimanana, J. U. Ganzhorn and S. M. Goodman (eds.), pp 19-53. Kluwer Academic Publishers, New York.

Godfrey, L. R., Jungers, W. L., Schwartz, G. T. and Irwin, M. T. 2008. Ghosts and orphans: Madagascar's vanishing ecosystems. In: Elwyn Simons: A Search for Origins. J. G. Fleagle and C. C. Gilbert (eds.), pp 361-395. springer, New York.

Godfrey, L. R., Winchester, J. M., King, S. J., Boyer, D. M. and Jernvall, J. 2012 Dental topography indicates ecological contraction of lemur communities. American Journal of Physical Anthropology 148, 2: 215-227. (doi:10.1002/ajpa.21615)

Goodman, S. M. and Benstead, J. P. 2005. Updated estimates of biotic diversity and endemism for Madagascar. Oryx 39, 1: 73-77. (doi:10.1017/ S0030605305000128)

Goodman, S. M. and Rakotondravony, D. 1996. The Holocene distribution of Hypogeomys (Rodentia: Muridae: Nesomyinae) on Madagascar. In: Biogéographie de Madagascar. W. R. Lourenço (ed.), pp 283-293. ORSTOM, Paris.

Goodman, S. M. and Rakotozafy, L. M. A. 1997. Subfossil birds from coastal sites in western and southwestern Madagascar: A paleoenvironmental reconstruction. In: Natural Change and Human Impact in Madagascar. S. M. Goodman and B. D. Patterson (eds.), pp 257-279. Smithsonian Institution, Washington, D. C.

Goodman, S. M. and Ramanamanjato, J. B. 2007. A perspective on the paleoecology and biogeography of extreme southeastern Madagascar, with special reference to animals. In: Biodiversity, Ecology and Conservation of Littoral Ecosystems in Southeastern Madagascar, Tolagnaro (Fort Dauphin). J. U. Ganzhorn, S. M. Goodman and M. Vincelette (eds.), pp 25-48. Smithsonian Institution, Washington, D. C.

Goodman, S. M., Vasey, N. and Burney, D. A. 2006. The subfossil occurrence and paleoecological implications of Macrotarsomys petteri (Rodentia: Nesomyidae) in extreme southeastern Madagascar. Comptes Rendus Palevol 5: 953-962. (doi:10.1016/j.crpv.2006.09.008)

Goodman, S. M., Vasey, N. and Burney, D. A. 2007. Description of a new species of subfossil shrew tenrec (Afrosoricida: Tenrecidae: Microgale) from cave deposits in southeastern Madagascar. Proceedings of the Biological Society of Washington 120, 4: 367-376. (doi:10.2988/0006324X(2007)120[367:DOANSO]2.0.CO;2)

Jernvall, J., Wright, P. C., Ravoavy, F. L. and Simons, E. L. 2003. Report on findings of subfossils at Ampoza and Ampanihy in southwestern Madagascar. Lemur News 8: 21-23. 
Jouffroy, F.-K. 1963. Contribution à la connaissance du genre Archaeolemur, Filhol 1895. Annales de Paléontologie 49: 129-155.

Lamberton, C. 1934. Contribution à la connaissance de la faune subfossile de Madagascar. Lémuriens et Ratites: Les Megaladapis. Mémoires de l'Académie Malgache 17: 47-105.

Mahé, J. \& Sourdat, M. 1972. Sur l'extinction des vertébrés subfossiles et I'aridification du climat dans le Sud-ouest de Madagascar. Bulletin de la Société de Géologie de France 14: 295-309.

McCormac, F. G., Hogg, A. G., Blackwell, P. G., Buck, C. E., Higham, T. F. G. and Reimer, P. J. 2004. SHCal04 southern hemisphere calibration, 0-11.0 cal kyr BP. Radiocarbon 46, 3: 1087-1092.

Moat, J. and Smith, P. 2007. Atlas of the Vegetation of Madagascar. Kew Publishing, Royal Botanic Gardens, Kew.

Muldoon, K. M. 2010. Paleoenvironment of Ankilitelo Cave (late Holocene, southwestern Madagascar): Implications for the extinction of giant lemurs. Journal of Human Evolution 58, 4: 338-352. (doi:10.1016/j. jhevol.2010.01.005)

Muldoon, K. M. and Goodman, S. M. 2010. Ecological biogeography of Malagasy non-volant mammals: community structure is correlated with habitat. Journal of Biogeography 37, 6: 1144-1159. (doi:10.1111/ j.1365-2699.2010.02276.X)

Muldoon, K. M., DeBlieux, D. D., Simons, E. L. and Chatrath, P. J. 2009 The subfossil occurrence and paleoecological significance of small mammals at Ankilitelo Cave, southwestern Madagascar. Journal of Mammalogy 90, 5: 1111-1131. (doi:10.1644/08-MAMM-A-242.1)

Ramanamanjato, J.-B., Mcintyre, P. B. and Nussbaum, R. A. 2002. Reptile, amphibian, and lemur diversity of the Malahelo Forest, a biogeographical transition zone in southeastern Madagascar. Biodiversity and Conservation 11, 10: 1791-1807. (doi:10.1023/A:1020325415489)

Samonds, K. E. 2007. Late Pleistocene bat fossils from Anjohibe Cave, northwestern Madagascar. Acta Chiropterologica 9, 1: 39-65. (doi:10.3161/1733-5329(2007)9[39:LPBFFA]2.0.C0;2)

Steunes, S. 1989. Taxonomy, habits and relationships of the subfossil Madagascan hippopotami Hippopotamus lemerlei and H. madagascariensis. Journal of Vertebrate Paleontology 9, 3: 241-268. (doi:10.108 0/02724634.1989.10011761)

Stuiver, M. and Reimer, P. J. 1993. Extended ${ }^{14} \mathrm{C}$ database and revised Calib $3.0{ }^{14} \mathrm{C}$ age calibration program. Radiocarbon 35, 1: 215-230.

Virah-Sawmy, M., Bonsall, M. B. and Willis, K. J. 2009a. 'Tales of Symphonia': Extinction dynamics in response to past climate change in Madagascan rainforests. Biology Letters 5, 6: 821-825. (doi:10.1098/ rsbl.2009.0428)

Virah-Sawmy, M., Gillson, L. and Willis, K. J. 2009b. How does spatial heterogeneity influence resilience to climatic changes? Ecological dynamics in southeast Madagascar. Ecological Monographs 79, 4: 557-574. (doi:10.1890/08-1210.1)

Virah-Sawmy, M., Willis, K. J. and Gillson, L. 2010. Evidence for drought and forest declines during the recent megafaunal extinctions in Madagascar. Journal of Biogeography 37, 3: 506-519. (doi:10.1111/ j.1365-2699.2009.02203.x)

Weston, E. M. and Lister, A. M. 2009. Insular dwarfism in hippos and a model for brain size reduction in Homo floresiensis. Nature 456: 85-88. (doi:10.1038/nature07922)

Wilmé, L., Goodman, S. M. and Ganzhorn, J. U. 2006. Biogeographic evolution of Madagascar's microendemic biota. Science 312: 1063-1065.

(doi:10.1126/science.1122806) 